\title{
Fall-bearing Year Herbicides and Spring- nonbearing Year Foramsulfuron Applications for Hair Fescue Management in Lowbush Blueberry
}

\author{
Scott Neil White ${ }^{1}$ and Linshan Zhang ${ }^{1}$
}

AdDITIONAL INDEX wORDs. dichlobenil, Festuca filiformis, glufosinate, pronamide, terbacil, Vaccinium angustifolium, wild blueberry

SUMMARY. Hair fescue (Festuca filiformis) is a tuft-forming perennial grass that reduces yields in lowbush blueberry (Vaccinium angustifolium) fields. Nonbearing year foramsulfuron applications suppress hair fescue, but there is interest in increasing suppression through foramsulfuron use in conjunction with fall-applied herbicides. The objective of this research was to determine the main and interactive effects of fall-bearing year herbicide applications and spring-nonbearing year foramsulfuron applications on hair fescue. The experiment was a $5 \times 2$ factorial arrangement of fall-bearing year herbicide (none, terbacil, pronamide, glufosinate, dichlobenil) and spring-nonbearing year foramsulfuron application $\left(0,35 \mathrm{~g} \cdot \mathrm{ha}^{-1}\right)$ arranged in a randomized complete block design at lowbush blueberry fields in Portapique and Stewiacke, Nova Scotia, Canada. Spring-nonbearing year foramsulfuron applications did not reduce total tuft density or consistently reduce flowering tuft density, flowering tuft inflorescence number, or flowering tuft seed production. Fall-bearing year pronamide applications reduced hair fescue density for the 2-year production cycle, although additional bearing year density reductions occurred when pronamide was followed by spring-nonbearing year foramsulfuron applications at Stewiacke. Fall-bearing year dichlobenil applications reduced total and flowering tuft density at each site, although reductions in flowering tuft inflorescence number and seed production were most consistent when followed by spring-nonbearing year foramsulfuron applications at Stewiacke. Suppression extended into the bearing year at each site, and dichlobenil should be examined further for hair fescue control. Fall-bearing year glufosinate applications reduced hair fescue total tuft density at each site and flowering tuft density and flowering tuft seed production at Stewiacke. Fall-bearing year glufosinate applications followed by spring-nonbearing year foramsulfuron applications also reduced nonbearing year flowering tuft inflorescence number and bearing year hair fescue seedling density at Stewiacke, indicating that this treatment may reduce hair fescue seedling recruitment at some sites. Fall-bearing year terbacil applications did not suppress hair fescue and are not recommended for hair fescue management in lowbush blueberry.

$\mathrm{L}$

owbush blueberry ( $V$. angustifolium) is an economically important fruit crop in Canada

Received for publication 13 July 2020. Accepted for publication 4 Sept. 2020.

Published online 5 October 2020.

${ }^{1}$ Department of Plant, Food, and Environmental Sciences, Dalhousie University Faculty of Agricultural, Truro, NS, B2N 5E3, Canada

We acknowledge field assistance from Hugh Lyu, Cody Webb, Lienna Hoeg, and Tyler Jollimore. Field sites for this research were provided by Bragg Lumber Company and Joe Slack. Funding for this research was provided by the Wild Blueberry Producers Association of Nova Scotia, Dalhousie University, and the Nova Scotia Department of Agriculture through a Research Acceleration Grant (grant no. RAl5-0009) to S.N.W.

S.N.W. is the corresponding author. E-mail: scott. white@dal.ca.

This is an open access article distributed under the $\mathrm{CC}$ BY-NC-ND license (https://creativecommons.org/ licenses/by-nc-nd/4.0/).

https://doi.org/10.21273/HORTTECH04677-20 that contributed $\$ 47.4$ million CAD to farm gate value in 2017 (Agriculture and Agri-Food Canada, 2019). The plant is a rhizomatous perennial shrub (Hall et al., 1979; Pritts and Hancock, 1984) and commercial fields are developed from natural stands (Agriculture and Agri-Food
Canada, 2019) that are managed under a 2 -year production cycle. Plants are pruned to ground level by flail mowing in the first year (nonbearing year) to promote vegetative growth and emergence of new shoots from the rhizomes and emerged shoots flower and produce berries in the second year (bearing year) (Eaton et al., 2004; Wood, 2004). Weed management is difficult because of lack of tillage and crop rotation and the weed flora is dominated by woody and herbaceous perennial weeds (McCully et al., 1991), including several species of perennial grasses (Agriculture and Agri-Food Canada, 2019; Jensen and Yarborough, 2004).

Hair fescue (Festuca filiformis) is a common, tufted perennial grass in lowbush blueberry fields. Tufts form dense, competitive sods that can reduce lowbush blueberry yield by $>50 \%$ (White, 2019; Zhang, 2017; Zhang et al., 2018). Many growers are also unable to harvest fields with hair fescue infestations due to inability of mechanical harvesters to move through dense tufts. Hair fescue is not controlled by preemergence nonbearing year hexazinone applications (White, 2019) and efficacy of preemergence nonbearing year terbacil applications is variable and limited primarily to suppression (White, 2019; Zhang et al., 2018). Postemergence foramsulfuron applications were recently registered for nonbearing year hair fescue suppression in lowbush blueberry and reduce flowering tuft density, flowering tuft inflorescence number, and flowering tuft seed production and seed viability (White and Kumar, 2017). However, efficacy is variable across sites and large tufts common in lowbush blueberry fields are not killed (Zhang et al., 2018). There is, therefore, interest from growers to use foramsulfuron as a sequential application in

\begin{tabular}{llll}
\hline $\begin{array}{l}\text { Units } \\
\text { To convert U.S. to SI, } \\
\text { multiply by }\end{array}$ & U.S, unit & SI unit & $\begin{array}{l}\text { To convert SI to U.S., } \\
\text { multiply by }\end{array}$ \\
\hline 0.4047 & $\mathrm{acre}(\mathrm{s})$ & $\mathrm{ha}$ & 2.4711 \\
0.3048 & $\mathrm{ft}$ & $\mathrm{m}$ & 3.2808 \\
0.0929 & $\mathrm{ft}^{2}$ & $\mathrm{~m}^{2}$ & 10.7639 \\
3.7854 & $\mathrm{gal}$ & $\mathrm{L}$ & 0.2642 \\
9.3540 & gal/acre & $\mathrm{L} \cdot \mathrm{ha}^{-1}$ & 0.1069 \\
2.54 & inch(es) & $\mathrm{cm}$ & 0.3937 \\
1.1209 & lb/acre & $\mathrm{kg} \cdot \mathrm{ha}^{-1}$ & 0.8922 \\
70.0532 & oz/acre & $\mathrm{g} \cdot \mathrm{ha}^{-1}$ & 0.0143 \\
6.8948 & $\mathrm{psi}$ & $\mathrm{kPa}$ & 0.1450
\end{tabular}


conjunction with other fall- or springapplied herbicides, as this may improve hair fescue suppression (White and Kumar, 2017; White, 2019) and diversify the herbicide modes of action used to manage this weed species.

Herbicides currently registered for fall-bearing year applications in lowbush blueberry and that also have known or potential efficacy on hair fescue are limited to pronamide, dichlobenil, glufosinate, and terbacil. Pronamide is effective (White, 2019) and is considered the industry standard treatment for hair fescue. Dichlobenil is not widely used in lowbush blueberry due to high cost of broadcast applications (>\$1400 CAD/ha), but suppressed red fescue (Festuca rubra) in lowbush blueberry (Sikoryia, 2014) and could provide an important alternative herbicide mode of action for hair fescue if effective. Fall-bearing year glufosinate applications alone do not control hair fescue but can reduce flowering tuft density and may increase suppression when followed by spring-nonbearing year foramsulfuron applications (White, 2019). This glufosinate use pattern, however, has not been widely evaluated. Fall-bearing year terbacil applications are registered for use in lowbush blueberry (New Brunswick Department of Agriculture, Aquaculture, and Fisheries, 2017) but are rarely used because previous research indicated lower weed control from fall relative to spring applications (Jensen, 1985a, 1985b). Fall-bearing year applications have not, however, been evaluated on a perennial grass such as hair fescue.

The objective of this research was to determine the main and interactive effects of fall-bearing year pronamide, dichlobenil, glufosinate, and terbacil applications and spring-nonbearing year foramsulfuron applications on hair fescue in lowbush blueberry fields.

\section{Materials and methods}

The experiment was conducted in lowbush blueberry fields located at Portapique (lat. $45^{\circ} 24^{\prime} 36.85^{\prime \prime} \mathrm{N}$, long. $\left.63^{\circ} 43^{\prime} 28.07^{\prime \prime} \mathrm{W}\right)$ and Stewiacke (lat. $45^{\circ} 16^{\prime} 18.68^{\prime \prime} \mathrm{N}$, long. $\left.63^{\circ} 4^{\prime} 36.49^{\prime \prime} \mathrm{W}\right)$, Nova Scotia, Canada, and was established on 8 Oct. 2015 at Portapique and 6 Nov. 2015 at Stewiacke. Soil at the Portapique site was a sandy loam (70\% sand, $21 \%$ silt, $9 \%$ clay) with $\mathrm{pH}$ of 4.4 and $9 \%$ organic matter (OM). Soil at the Stewiacke site was a sandy loam (74\% sand, $18 \%$ silt, $8 \%$ clay) with $\mathrm{pH}$ of 4.6 and $6 \%$ OM. The experiment was a $5 \times 2$ factorial arrangement of fall-bearing year herbicide [none, terbacil (Sinbar 80WDG herbicide; Tessenderlo Kerley, Phoenix, AZ), pronamide (Kerb SC herbicide; Dow AgroSciences Canada, Calgary, $\mathrm{AB}$, Canada), glufosinate (Ignite herbicide; Bayer CropScience, Durham, NC), and dichlobenil (Casoron G-4 Herbicide; MacDermid Agricultural Solutions, Guelph, ON, Canada)] and spring-nonbearing year foramsulfuron (Option 2.25 OD herbicide; Bayer CropScience, Calgary, AB, Canada) application $\left(0,35 \mathrm{~g} \cdot \mathrm{ha}^{-1}\right)$ arranged in a randomized complete block design with four blocks and $2 \times$ 6-m plot size at each site. Application rates of terbacil, pronamide, glufosinate, and dichlobenil were 2000, 2240,750 , and $7000 \mathrm{~g} \cdot \mathrm{ha}^{-1}$, respectively. Foramsulfuron was applied with a liquid nitrogen fertilizer $(28 \%$ urea ammonium nitrate) at a rate of $2.5 \mathrm{~L} \cdot \mathrm{ha}^{-1}$ as per label instructions. Fall-bearing year herbicides were applied on 10 Nov. 2015 at Portapique and 11 Nov. 2015 at Stewiacke. Spring-nonbearing year foramsulfuron applications were applied on 10 May 2016 at Portapique and on 4 May 2016 at Stewiacke. Herbicides were applied using a carbon dioxide $\left(\mathrm{CO}_{2}\right)$ pressurized research plot sprayer outfitted with four nozzles $\left[110^{\circ}\right.$ spray angle, $0.2 \mathrm{gal} / \mathrm{min}$, extended range (11002 XR; TeeJet Technologies, Wheaton, IL)] and calibrated to deliver a water volume of $300 \mathrm{~L} \cdot \mathrm{ha}^{-1}$ (pronamide) or 200 $\mathrm{L} \cdot \mathrm{ha}^{-1}$ (terbacil, pronamide, glufosinate, and foramsulfuron) at a pressure of 40 psi. Dichlobenil was applied directly to the soil by hand.

Data collection included hair fescue tuft density before treatment applications, vegetative and flowering hair fescue tuft density in summer of the nonbearing and bearing year, hair fescue flowering tuft inflorescence number in summer of the nonbearing year, hair fescue seed production in fall of nonbearing year, hair fescue seedling density in early summer of the bearing year, lowbush blueberry stem density, stem height, and flower bud number per stem at the end of the nonbearing year, and lowbush blueberry yield in late summer of the bearing year. Hair fescue tuft densities were determined in two $1 \times 1-\mathrm{m}$ quadrats per plot. Hair fescue inflorescence number was determined on 10 randomly selected tufts/plot using a line transect method previously described (White and Kumar, 2017). Hair fescue seed production was determined by collecting all inflorescences from five randomly selected hair fescue tufts in each plot and counting all seeds retained on the inflorescences. Hair fescue seedling densities were counted in three $30 \times$ $30-\mathrm{cm}$ quadrats per plot. Initial hair fescue tuft densities were determined on 10 Nov. 2015 at Portapique and 11 Nov. 2015 at Stewiacke. Nonbearing year hair fescue flowering and vegetative tuft densities were determined on 27 June 2016 at Portapique and 19 June 2016 at Stewiacke. Nonbearing year flowering hair fescue tuft inflorescence number was determined on 8 July 2016 at Portapique and 7 July 2016 at Stewiacke. Hair fescue inflorescences were collected for seed production estimation on 5 Oct. 2016 at Portapique and Stewiacke. Hair fescue seedling densities in the bearing year were determined on 24 May 2017 at Portapique and 26 May 2017 at Stewiacke. Bearing year hair fescue flowering and vegetative tuft densities were determined on 29 June 2017 at Portapique and 7 July 2017 at Stewiacke.

Lowbush blueberry stem density was determined in two $30 \times 30-\mathrm{cm}$ quadrats per plot. Lowbush blueberry stem height and flower buds per stem were determined on 30 randomly selected blueberry stems per plot. Stems were clipped at ground level, bagged in the field, and brought back to the laboratory for data collection. Lowbush blueberry yield was determined in two $1 \times 1-\mathrm{m}$ quadrats per plot and fruit was harvested using hand rakes in mid-August of the bearing year. Lowbush blueberry stem density was determined on 20 Oct. 2016 at Portapique and 5 Oct. 2016 at Stewiacke. Stem collections for height and flower bud assessment at each site occurred on these dates as well. Lowbush blueberry yield was determined on 3 Aug. 2017 at Stewiacke but could not be determined at Portapique because of variable plot coverage by blueberry plants at this site. 
Statistical analysis. The effects of site, fall-bearing year herbicide applications, spring-nonbearing year foramsulfuron applications, and the subsequent interactions on the various response variables were determined using analysis of variance in PROC MIXED in SAS for Windows (version 9.4 for Windows; SAS Institute, Cary, NC). Main and interaction effects were modeled as fixed effects in the analysis, and blocks were modeled as a random effect. Assumptions of normality and constant variance for all analyses were assessed using PROC UNIVARIATE in SAS, and data were natural logarithm $(\mathrm{Y}+\mathrm{l})$ or square root $(\mathrm{Y}+\mathrm{l})$ transformed where necessary to achieve normality and constant variance. Means separation, where necessary, was conducted using a Tukey's test at a probability level of $P<0.05$.

\section{Results and discussion}

Treatment effects ON HaIR FESCUE. There was a significant site effect on nonbearing year hair fescue seed production $(P=0.004)$, bearing year hair fescue seedling density $(P<$ 0.0001 ), and bearing year hair fescue flowering tuft density $(P=0.02)$ and total tuft density $(P=0.01)$. There was also a significant site $\times$ fall-bearing year herbicide application interaction on nonbearing year hair fescue flowering tuft density $(P=0.009)$, total tuft density $(P=0.016)$, hair fescue seed production $(P=0.002)$, and bearing year hair fescue seedling density $(P=0.003)$, flowering tuft density $(P=0.004)$, and total tuft density $(P<0.0001)$. Sites were therefore analyzed separately.

Initial hair fescue tuft densities were (mean \pm SE) $37 \pm 13$ and $36 \pm 12$ tufts $/ \mathrm{m}^{2}$ at Portapique and Stewiacke, respectively. Nonbearing year hair fescue total tuft density, flowering tuft inflorescence number, and seed production, as well as bearing year hair fescue total tuft density and flowering tuft density were affected primarily by fall-bearing year herbicide applications at Portapique (Tables 1 and 2). These data were therefore pooled by fall-bearing year herbicide for analysis. Nonbearing year hair fescue flowering tuft density and bearing year hair fescue seedling density at Portapique, however, were affected by both fall-bearing year herbicide and spring-nonbearing year foramsulfuron application (Tables 1 and 2) and these data were therefore analyzed based on the full factorial design. Nonbearing year response variables at Stewiacke were affected by most main and interactive effects (Table 1) and bearing year data were also largely affected by main effects of both fall-bearing year herbicide and spring-nonbearing year foramsulfuron application (Table 2). Nonbearing and bearing year data for Stewiacke were therefore analyzed according to the full factorial design.

Spring-nonbearing year foramsulfuron applications alone did not affect nonbearing year hair fescue total tuft density at Portapique (Tables 1 and 3 ) and did not reduce flowering tuft density at this site (Table 4). Nonbearing year total tuft density was not reduced at Stewiacke either, although spring-nonbearing year foramsulfuron applications reduced nonbearing year flowering tuft density at this site (Table 5). Nonbearing year flowering tuft inflorescence number and seed production were also unaffected by foramsulfuron at Portapique (Tables 1 and $3)$. Nonbearing year flowering tuft inflorescence number was not reduced by foramsulfuron at Stewiacke either, although seed production was reduced by spring-nonbearing year foramsulfuron applications at this site (Table 5). Spring foramsulfuron applications do not kill established tufts (White and Kumar, 2017) and, as such, generally do not reduce total tuft density (White and Kumar, 2017; Zhang, 2017; Zhang et al., 2018). Reductions in flowering tuft density and flowering tuft inflorescence number are also inconsistent (Zhang et al., 2018), and our results further demonstrate this inconsistency. Reasons for this inconsistency are unknown, but are likely the result of natural variability in hair fescue tuft size and tiller number in established populations in lowbush blueberry fields (S.N. White, personal observation). Foramsulfuron tank mixtures with nicosulfuron+rimsulfuron provide more consistent suppression across sites (S.N. White, unpublished data) and additional research is likely needed to identify foramsulfuron tank mixtures to improve hair fescue suppression with this herbicide, particularly given that bearing year total tuft density and flowering tuft density were not reduced by spring-nonbearing year foramsulfuron applications at either site (Tables 3 and 6).

Fall-bearing year pronamide applications reduced nonbearing year hair fescue total tuft density, flowering tuft density, and flowering tuft inflorescence number and seed production at each site (Tables 3-5). Subsequent spring-nonbearing year foramsulfuron applications did not provide further reductions in flowering tuft density at Portapique (Table 4 ) or any of these responses at Stewiacke (Table 5). Hair fescue total tuft density and flowering tuft density remained low at each site in the pronamide treatments in the bearing year (Tables 3 and 6), indicating good control of hair fescue across the entire 2 -year production cycle from pronamide. Fall pronamide applications provide effective control of hair fescue (White, 2019; Zhang et al., 2018), and these results are not unexpected. Fall-bearing year pronamide applications followed by spring-nonbearing year foramsulfuron applications did, however, provide additional reductions in bearing year total tuft density at Stewiacke (Table 6). Living tufts were still present in pronamide treatments in the nonbearing year at each site (Tables 3 and 5 ) and results from Stewiacke indicate that growers may obtain additional control by treating surviving tufts with foramsulfuron following fall pronamide applications. Fall-bearing year pronamide applications also reduced bearing year hair fescue seedling density at each site (Tables 4 and 6), indicating that reductions in nonbearing year seed production by this herbicide limits reestablishment of hair fescue from seed in the bearing year.

Fall-bearing year dichlobenil applications reduced nonbearing year hair fescue total tuft density, flowering tuft density, and flowering tuft inflorescence number at each site (Tables 3-5). Fall-bearing year dichlobenil applications also reduced hair fescue flowering tuft seed production at each site (Tables 3 and 5), and subsequent spring-nonbearing year foramsulfuron applications generally contributed to increased reductions in seed production at Stewiacke (Table 5). Total tuft density and flowering tuft density remained low in the bearing year at Portapique (Table 3), and fall-bearing year 
Table 1. Significance of main and interactive effects of fall-bearing year herbicide applications and spring-nonbearing year foramsulfuron applications on nonbearing year hair fescue total tuft density, flowering tuft density, flowering tuft inflorescence number, and seed production in lowbush blueberry fields at Portapique and Stewiacke, NS, Canada in 2016.

\begin{tabular}{|c|c|c|c|c|c|}
\hline Site & Effect & $\begin{array}{c}\text { Total tuft } \\
\text { density }\end{array}$ & $\begin{array}{l}\text { Flowering tuft } \\
\text { density }\end{array}$ & $\begin{array}{l}\text { Inflorescence } \\
\text { no. }\end{array}$ & $\begin{array}{c}\text { Seed } \\
\text { production }\end{array}$ \\
\hline \multirow[t]{3}{*}{ Portapique } & Fall-bearing year herbicide application & $P<0.0001^{\mathrm{z}}$ & $P<0.0001$ & $P<0.0001$ & $P<0.0001$ \\
\hline & $\begin{array}{l}\text { Spring-nonbearing year foramsulfuron } \\
\text { application }\end{array}$ & $P=0.53$ & $P=0.04$ & $P=0.23$ & $P=0.16$ \\
\hline & $\begin{array}{l}\text { Fall-bearing year herbicide application } \times \\
\text { spring-nonbearing year foramsulfuron } \\
\text { application }\end{array}$ & $P=0.97$ & $P=0.95$ & $P=0.40$ & $P=0.40$ \\
\hline \multirow{2}{*}{ Stewiacke } & $\begin{array}{l}\text { Spring-nonbearing year foramsulfuron } \\
\text { application }\end{array}$ & $P=0.002$ & $P<0.0001$ & $P=0.0001$ & $P<0.0001$ \\
\hline & $\begin{array}{l}\text { Fall-bearing year herbicide application } \times \\
\text { spring-nonbearing year foramsulfuron } \\
\text { application }\end{array}$ & $P=0.014$ & $P<0.0001$ & $P=0.06$ & $P=0.001$ \\
\hline
\end{tabular}

${ }^{\mathrm{z}}$ Probability values obtained from analysis of variance using PROC MIXED in SAS (version 9.4 for Windows; SAS Institute, Cary, NC). Main and interactive effects considered significant at $P<0.05$.

Table 2. Significance of main and interactive effects of fall-bearing year herbicide applications and spring-nonbearing year foramsulfuron applications on bearing year hair fescue total tuft density, flowering tuft density, and hair fescue seedling density in lowbush blueberry fields at Portapique and Stewiacke, NS, Canada in 2017.

\begin{tabular}{|c|c|c|c|c|}
\hline Site & Effect & $\begin{array}{c}\text { Total tuft } \\
\text { density }\end{array}$ & $\begin{array}{c}\text { Flowering tuft } \\
\text { density }\end{array}$ & $\begin{array}{l}\text { Seedling } \\
\text { density }\end{array}$ \\
\hline \multirow[t]{3}{*}{ Portapique } & Fall-bearing year herbicide application & $P<0.0001^{z}$ & $P<0.0001$ & $P<0.0001$ \\
\hline & Spring-nonbearing year foramsulfuron application & $P=0.55$ & $P=0.54$ & $P=0.017$ \\
\hline & $\begin{array}{l}\text { Fall-bearing year herbicide application } \times \text { spring-nonbearing } \\
\text { year foramsulfuron application }\end{array}$ & $P=0.97$ & $P=0.86$ & $P=0.40$ \\
\hline Stewiacke & Fall-bearing year herbicide application & $P<0.0001$ & $P<0.0001$ & $P<0.0001$ \\
\hline
\end{tabular}

${ }^{\mathrm{z}}$ Probability values obtained from analysis of variance using PROC MIXED in SAS (version 9.4 for Windows; SAS Institute, Cary, NC). Main and interactive effects considered significant at $P<0.05$

dichlobenil applications followed by spring-nonbearing year foramsulfuron applications also reduced bearing year seedling density at this site (Table 4). Bearing year flowering tuft density and seedling density were also reduced at Stewiacke (Table 6). These results indicate that hair fescue control from fall-bearing year dichlobenil applications can extend into the bearing year, providing an important new use for this herbicide. Although registered for use in lowbush blueberry, dichlobenil is seldom used by lowbush blueberry growers because of high product cost for broadcast applications (>\$1400 CAD/ha). Efficacy on hair fescue, however, indicates that identification of economical uses of dichlobenil would be beneficial to lowbush blueberry growers as this herbicide provides an important alternative herbicide site of action for hair fescue management in this crop. This herbicide can, for example, be applied as a spot application with small hand-held equipment (MacDermid Agricultural Solutions, 2014). Hair fescue seeds are also dispersed by harvesting equipment (Boyd and White, 2009), and growers could consider dichlobenil for control of hair fescue in field areas where harvesters or other equipment enter fields and are parked before use. Variable-rate granular applicators are also available (Fulton et al., 2003; Miller et al., 2005) and could be evaluated for precision dichlobenil applications for hair fescue management in lowbush blueberry fields.

Fall-bearing year glufosinate applications alone reduced nonbearing year hair fescue total tuft density at each site (Tables 3 and 5), although effects on other response variables varied across sites. Fall-bearing year glufosinate applications reduced nonbearing year flowering tuft inflorescence number at Portapique (Table
3), but did not reduce seed production or flowering tuft density at this site (Tables 3 and 4 ). In contrast, fallbearing year glufosinate applications alone reduced nonbearing year hair fescue flowering tuft density and seed production at Stewiacke (Table 5) and, when followed by spring-nonbearing year foramsulfuron applications, provided additional reductions in flowering tuft density and seed production and also reduced flowering tuft inflorescence number (Table $5)$. Glufosinate applications kill hair fescue seedlings and small tufts (White, 2018; White and Kumar, 2017), and reductions in nonbearing year total tuft density at each site may reflect this, particularly at Stewiacke, as this site had smaller hair fescue tufts than Portapique based on visual observation. Hair fescue tillers also have a vernalization requirement for flowering (White, 2018), and reductions in hair fescue flowering tuft density, 
Table 3. Effect of fall-bearing year herbicide applications on nonbearing year hair fescue total tuft density, flowering tuft inflorescence number, and flowering tuft seed production and on bearing year hair fescue total tuft density and flowering tuft density at Portapique, NS, Canada, in 2016 (nonbearing year) and 2017 (bearing year).

\begin{tabular}{|c|c|c|c|c|c|}
\hline \multirow{4}{*}{$\begin{array}{l}\text { Fall-bearing yr } \\
\text { herbicide }\end{array}$} & \multicolumn{3}{|c|}{ Nonbearing $\mathrm{yr}^{\mathrm{z}}$} & \multicolumn{2}{|c|}{ Bearing yr } \\
\hline & \multirow{2}{*}{$\begin{array}{l}\text { Total tuft density } \\
\left(\text { no. } / \mathrm{m}^{2}\right)^{\mathrm{y}}\end{array}$} & \multirow{2}{*}{$\begin{array}{c}\text { Inflorescences } \\
\text { (no./tuft) }\end{array}$} & \multirow{2}{*}{$\begin{array}{l}\text { Seed production } \\
\text { (no./tuft) }\end{array}$} & $\begin{array}{l}\text { Total tuft } \\
\text { density }\end{array}$ & $\begin{array}{c}\text { Flowering tuft } \\
\text { density }\end{array}$ \\
\hline & & & & \multicolumn{2}{|c|}{$\left(\right.$ no. $\left./ \mathrm{m}^{2}\right)$} \\
\hline & & & nean $\pm S E$ & & \\
\hline None & $6.1 \pm 0.38 \mathrm{a}^{\mathrm{x}}(37)$ & $5.7 \pm 0.47$ a $(36)$ & $31 \pm 2.8 \mathrm{a}(971)$ & $32 \pm 2 \mathrm{a}$ & $21 \pm 2 a$ \\
\hline Pronamide & $1.8 \pm 0.38 c(3)$ & $\mathrm{l} \pm 0.47 \mathrm{~d}(0)$ & $1 \pm 2.8 \mathrm{~b}(0)$ & $2 \pm 2 b$ & $1 \pm 2 b$ \\
\hline Terbacil & $5.2 \pm 0.38 \mathrm{ab}(27)$ & $5.1 \pm 0.47 \mathrm{ab}(27)$ & $30 \pm 2.8$ a $(966)$ & $27 \pm 2 \mathrm{a}$ & $19 \pm 2 \mathrm{a}$ \\
\hline
\end{tabular}

${ }^{\mathrm{z}}$ Nonbearing year total tuft density, inflorescence number, and seed production data were square root $(\mathrm{Y}+\mathrm{l})$ transformed to meet the assumptions of the variance analysis. Transformed means are presented for variance estimates and means comparison purposes, and back-transformed means are presented in parentheses.

y tuft $/ \mathrm{m}^{2}=0.0929 \mathrm{tuft} / \mathrm{ft}^{2}$.

${ }^{\mathrm{x}}$ Means within columns with different letters are significantly different at $P<0.05$ according to Tukey's test.

Table 4. Effect of fall-bearing year herbicide applications and spring-nonbearing year foramsulfuron applications on nonbearing year hair fescue flowering tuft density and on bearing year hair fescue seedling density at Portapique, NS, Canada, in 2016 (nonbearing year) and 2017 (bearing year).

\begin{tabular}{|c|c|c|c|}
\hline \multirow{2}{*}{$\begin{array}{l}\text { Fall-bearing yr } \\
\text { herbicide }\end{array}$} & \multirow{2}{*}{$\begin{array}{l}\text { Spring-nonbearing yr } \\
\text { foramsulfuron }\left(\mathrm{g} \cdot \mathrm{ha}^{-1}\right)^{\mathrm{z}}\end{array}$} & $\begin{array}{l}\text { Nonbearing yr flowering } \\
\text { tuft density }\left(\text { no. } / \mathrm{m}^{2}\right)^{\mathrm{z}}\end{array}$ & $\begin{array}{c}\text { Bearing yr seedling } \\
\text { density }\left(\text { no. } / \mathrm{m}^{2}\right)\end{array}$ \\
\hline & & \multicolumn{2}{|c|}{ mean $\pm \mathrm{SE}$} \\
\hline None & 0 & $16 \pm 2 a^{y}$ & $123 \pm 21 a$ \\
\hline Pronamide & 0 & $1 \pm 2 b c$ & $6 \pm 21 c$ \\
\hline Dichlobenil & 0 & $2 \pm 2 b c$ & $39 \pm 21 \mathrm{abc}$ \\
\hline Glufosinate & 0 & $12 \pm 2 a$ & $105 \pm 21 \mathrm{a}$ \\
\hline Pronamide & 35 & $0 \mathrm{c}$ & $3 \pm 21 \mathrm{c}$ \\
\hline Dichlobenil & 35 & $0 \mathrm{c}$ & $10 \pm 21 b c$ \\
\hline Glufosinate & 35 & $9 \pm 2 \mathrm{abc}$ & $44 \pm 21 \mathrm{abc}$ \\
\hline Terbacil & 35 & $10 \pm 2 \mathrm{ab}$ & $61 \pm 21 \mathrm{abc}$ \\
\hline
\end{tabular}

${ }^{\mathrm{z}} \mathrm{l} \mathrm{g} \cdot \mathrm{ha}^{-1}=0.0143 \mathrm{oz} /$ acre, $\mathrm{l} \mathrm{tuft} / \mathrm{m}^{2}=0.0929 \mathrm{tuft} / \mathrm{ft}^{2}, \mathrm{l}$ seedling $/ \mathrm{m}^{2}=0.0929$ seedling $/ \mathrm{ft}^{2}$.

${ }^{y}$ Means within columns with different letters are significantly different at $P<0.05$ according to Tukey's test.

inflorescence number, and seed production by fall glufosinate applications likely reflect disruption of this physiological process by glufosinate injury. Sequential fall or spring glufosinate and foramsulfuron applications have not consistently improved hair fescue suppression relative to spring foramsulfuron applications alone (White, 2019; White and Kumar, 2017; Zhang, 2017). Results from Stewiacke, however, suggest that sequential treatments are more effective than foramsulfuron applications alone and that fall-bearing year glufosinate applications, alone or in conjunction with spring-nonbearing year foramsulfuron applications, may contribute to nonbearing year hair fescue management in lowbush blueberry fields. Fall-bearing year glufosinate applications followed by spring-nonbearing year foramsulfuron applications also reduced bearing year hair fescue seedling density at Stewiacke
(Table 6) and may therefore help reduce bearing year hair fescue seedling recruitment at some sites. Glufosinate applications, alone or in combination with spring-nonbearing year foramsulfuron applications, however, did not reduce bearing year total tuft density or flowering tuft density at either site (Tables 3 and $6)$, indicating limited long-term suppression of established hair fescue tufts by glufosinate. This herbicide therefore needs to be used in conjunction with other herbicides, such as pronamide, to maintain hair fescue control in the bearing year.

Although labeled for use in lowbush blueberry, fall-bearing year terbacil applications did not reduce nonbearing year hair fescue total tuft density at either site (Tables 3 and 5 ) and only reduced nonbearing year total tuft density, flowering tuft density, flowering tuft inflorescence number, and seed production when used in conjunction with spring-nonbearing year foramsulfuron applications at Stewiacke (Table 5). Springnonbearing year foramsulfuron applications alone, however, generally provided similar suppression at Stewiacke as fall-bearing year terbacil applications followed by spring-nonbearing year foramsulfuron applications (Table 5). Fall-bearing year terbacil applications are therefore not recommended for hair fescue management in lowbush blueberry. Spring-nonbearing year terbacil applications, however, suppress hair fescue (White, 2019; Zhang et al., 2018), and terbacil kills hair fescue seedlings (White, 2018). This herbicide may therefore contribute to hair fescue management through use of spring-nonbearing year rather than fall-bearing year applications. Fall-bearing year terbacil applications, alone or followed by foramsulfuron, did not reduce bearing year hair fescue tuft density or 
Table 5. Effect of fall-bearing year herbicide applications and spring-nonbearing year foramsulfuron applications on nonbearing year hair fescue total tuft density, flowering tuft density, flowering tuft inflorescence number, and flowering tuft seed production at Stewiacke, NS, Canada, in 2016.

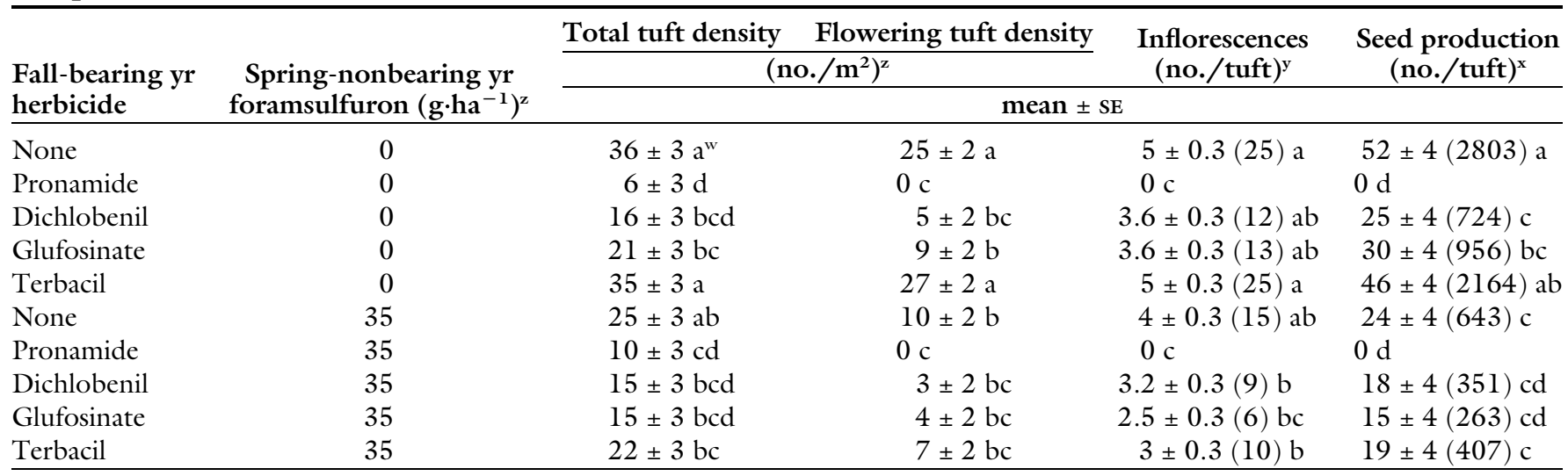

${ }^{\mathrm{z}} 1 \mathrm{~g} \cdot \mathrm{ha}^{-1}=0.0143 \mathrm{oz} /$ acre, $1 \mathrm{tuft} / \mathrm{m}^{2}=0.0929 \mathrm{tuft} / \mathrm{ft}^{2}$

${ }^{\mathrm{y}}$ Inflorescence number data were square root $(\mathrm{Y}+\mathrm{l})$ transformed to meet the assumptions of the variance analysis. Transformed means are presented for variance estimates and means comparison purposes, and back-transformed means are presented in parentheses.

${ }^{\mathrm{x}}$ Seed production data were square root $(\mathrm{Y}+\mathrm{l})$ transformed to meet the assumptions of the variance analysis. Transformed means are presented for variance estimates and means comparison purposes, and back-transformed means are presented in parentheses.

${ }^{w}$ Means within columns with different letters are significantly different at $P<0.05$ according to Tukey's test.

Table 6. Effect of fall-bearing year herbicide applications and spring-nonbearing year foramsulfuron applications on bearing year hair fescue total tuft density, flowering tuft density, and seedling density at Stewiacke, NS, Canada, in 2017.

\begin{tabular}{|c|c|c|c|c|}
\hline \multirow{3}{*}{$\begin{array}{l}\text { Fall-bearing yr } \\
\text { herbicide }\end{array}$} & \multirow{3}{*}{$\begin{array}{l}\text { Spring-nonbearing yr } \\
\text { foramsulfuron }\left(\mathrm{g} \cdot \mathrm{ha}^{-1}\right)^{\mathrm{z}}\end{array}$} & Total tuft density & Flowering tuft density & \multirow{2}{*}{$\begin{array}{l}\text { Seedling density } \\
\left(\text { no. } / \mathrm{m}^{2}\right)^{\mathrm{z}, \mathrm{x}}\end{array}$} \\
\hline & & \multicolumn{2}{|c|}{$\left(\text { no. } / \mathrm{m}^{2}\right)^{\mathrm{z}}$} & \\
\hline & & & mean $\pm \mathrm{SE}$ & \\
\hline Pronamide & 0 & $3.3 \pm 0.2(10) b$ & $4 \pm 1.4 \mathrm{de}$ & $2.1 \pm 0.3(4) \mathrm{de}$ \\
\hline Dichlobenil & 0 & $4.5 \pm 0.2(20) \mathrm{a}$ & $10 \pm 1.4 \mathrm{~cd}$ & $3.5 \pm 0.3(11) \mathrm{bcd}$ \\
\hline Glufosinate & 0 & $4.7 \pm 0.2(22) \mathrm{a}$ & $16 \pm 1.4 \mathrm{abc}$ & $5.1 \pm 0.3(26) \mathrm{a}$ \\
\hline Pronamide & 35 & $1.8 \pm 0.2(3) \mathrm{c}$ & $1 \pm 1.4 \mathrm{e}$ & $1.3 \pm 0.3(1) \mathrm{e}$ \\
\hline Dichlobenil & 35 & $4.4 \pm 0.2(18) \mathrm{a}$ & $11 \pm 1.4 \mathrm{bc}$ & $2.6 \pm 0.3(6) \mathrm{cde}$ \\
\hline Glufosinate & 35 & $4.5 \pm 0.2(20) \mathrm{a}$ & $13 \pm 1.4 \mathrm{abc}$ & $3.5 \pm 0.3(12) \mathrm{bcd}$ \\
\hline Terbacil & 35 & $4.8 \pm 0.2(23) \mathrm{a}$ & $16 \pm 1.4 \mathrm{abc}$ & $4.3 \pm 0.3(17) \mathrm{ab}$ \\
\hline
\end{tabular}

${ }^{\mathrm{z}} \mathrm{l} \mathrm{g} \cdot \mathrm{ha}^{-1}=0.0143 \mathrm{oz} /$ acre, $\mathrm{l}$ tuft $/ \mathrm{m}^{2}=0.0929 \mathrm{tuft} / \mathrm{ft}^{2}, \mathrm{l}$ seedling $/ \mathrm{m}^{2}=0.0929$ seedling $/ \mathrm{ft}^{2}$.

${ }^{y}$ Total tuft density data were square root $(\mathrm{Y}+\mathrm{l})$ transformed to meet the assumptions of the variance analysis. Transformed means are presented for variance estimates and means comparison purposes, and back-transformed means are presented in parentheses.

${ }^{\mathrm{x}}$ Seedling density data were square $\operatorname{root}(\mathrm{Y}+\mathrm{l})$ transformed to meet the assumptions of the variance analysis. Transformed means are presented for variance estimates and means comparison purposes, and back-transformed means are presented in parentheses.

w Means within columns with different letters are significantly different at $P<0.05$ according to Tukey's test.

seedling density (Tables 3,4 , and 6 ) and once again appear ineffective on hair fescue. Jensen (1985b) reported that fall atrazine and terbacil applications gave less weed control than spring applications, and fall hexazinone applications also provided inferior weed control when compared with spring applications (Jensen, 1985a). Use of the soil-applied residual triazine and uracil herbicides should therefore remain limited to spring applications in lowbush blueberry.

TREATMENT EFFECTS ON LOWBUSH BLUEBERRY. There was no significant fall-bearing year herbicide effect, spring-nonbearing year foramsulfuron effect, or fall-bearing year herbicide by spring-nonbearing year foramsulfuron effect on lowbush blueberry stem density $(P \geq 0.11)$, stem height $(P \geq 0.49)$, or flower bud number/stem $(P \geq 0.30)$ at either site and no significant fall-bearing year herbicide effect $(P=0.41)$, springnonbearing year foramsulfuron effect $(P=0.56)$, or fall-bearing year herbicide by spring-nonbearing year foramsulfuron effect $(P=0.66)$ on lowbush blueberry yield at Stewiacke. Lowbush blueberry stem density, height, and flower bud number were $($ mean $\pm \mathrm{SE}) 208 \pm 23 \mathrm{stems} / \mathrm{m}^{2}, 13 \pm$ $0.4 \mathrm{~cm}$, and $5.2 \pm 0.3$ buds/stem, respectively, at Portapique and $267 \pm$ 24 stems $/ \mathrm{m}^{2}, 15 \pm 0.3 \mathrm{~cm}$, and $4.8 \pm$ 0.3 buds/stem, respectively, at Stewiacke. Mean lowbush blueberry yield at Stewiacke was $2164 \pm 325 \mathrm{~kg} \cdot \mathrm{ha}^{-1}$. Lowbush blueberry coverage was highly variable across the trial plots at each site, particularly Portapique, and many plots contained small patches of lowbush blueberry interspersed with bare areas colonized by hair fescue. Typical lowbush blueberry stem densities in high-yielding 
fields generally exceed $500 / \mathrm{m}^{2}$ or even 1000 stems $/ \mathrm{m}^{2}$ (Eaton, 1994; Ismail and Hanson, 1982; Penney and McRae, 2000), and large yield increases occur following hair fescue control under these conditions (White, 2019; Zhang, 2017). Lowbush blueberry populations in the trial areas at each site were therefore likely insufficient to detect positive yield responses following hair fescue control or suppression. Lowbush blueberry plants can also require up to 3 to 6 years to respond positively to weed control (Eaton 1994), and future research will therefore need to use effective treatments identified in this study in long-term weed control studies.

In conclusion, spring-nonbearing year foramsulfuron applications continue to provide variable levels of hair fescue suppression that is limited to the year of application only. Fallbearing year pronamide applications reduced nonbearing year hair fescue total tuft density, flowering tuft density, and flowering tuft inflorescence number and seed production. Tuft density reductions were still apparent in the subsequent bearing year, and bearing year hair fescue seedling density was also reduced. Pronamide is an effective herbicide for production-cycle suppression of hair fescue in lowbush blueberry. Additional suppression, however, may be achieved if surviving tufts are treated with spring-nonbearing year foramsulfuron applications. Fall-bearing year dichlobenil applications reduced nonbearing year hair fescue total tuft density and flowering tuft density, although reductions in flowering tuft inflorescence number and seed production were improved when fall-bearing year dichlobenil applications were followed by springnonbearing year foramsulfuron applications at Stewiacke. Density reductions were also apparent in the bearing year, and dichlobenil should be evaluated further for hair fescue management in lowbush blueberry. Fall-bearing year glufosinate applications reduced hair fescue total tuft density at each site and reduced flowering tuft density and flowering tuft seed production at Stewiacke, indicating that fall glufosinate applications contribute to hair fescue suppression in lowbush blueberry. Fall-bearing year glufosinate applications followed by spring-nonbearing year foramsulfuron applications also gave additional reductions in flowering tuft inflorescence number and seed production at Stewiacke. Hair fescue suppression, however, was limited to the nonbearing year and hair fescue recovered in the bearing year. Fall-bearing year terbacil applications were ineffective on hair fescue and are not recommended for hair fescue management in lowbush blueberry.

\section{Literature cited}

Agriculture and Agri-Food Canada. 2019. Crop profile for lowbush blueberry in Canada, 2017. Catalogue No. Al1810/31-2017-PDF. AAFC No. 12972E. Pest Management Program. Agric. AgriFood Canada, Ottawa, ON, Canada.

Boyd, N.S. and S. White. 2009. Impact of wild blueberry harvesters on weed seed dispersal within and between fields. Weed Sci. 57:541-546.

Eaton, L.J. 1994. Long-term effects of herbicide and fertilizers on lowbush blueberry growth and production. Can. J. Plant Sci. 74:341-345.

Eaton, L.J., R.W. Glen, and J.D. Wyllie. 2004. Efficient mowing for pruning wild blueberry fields. Small Fruits Rev. 3:123131.

Fulton, J.P., S.A. Shearer, T.S. Stombaugh, and S.F. Higgins. 2003. Comparison of variable-rate granular application equipment. Proc. Amer. Soc. Agr. Eng. Annu. Intl. Meet. Paper No. 031125 .

Hall, I.V., L.E. Alders, N.L. Nickerson, and S.P. Vander Kloet. 1979. The biological flora of Canada. 1. Vaccinium angustifolium Ait., sweet lowbush blueberry. Can. Field Nat. 93:415-430.

Ismail, A.A. and E.J. Hanson. 1982. Interaction of method and date of pruning on growth and productivity of the lowbush blueberry. Can. J. Plant Sci. 62:677682 .

Jensen, K.I.N. 1985a. Weed control in lowbush blueberry in eastern Canada. Acta Hort. 165:259-265.

Jensen, K.I.N. 1985b. Tolerance and residues of hexazinone in lowbush blueberries. Can. J. Plant Sci. 65:223-227.

Jensen, K.I.N. and D.E. Yarborough. 2004. An overview of weed management in the wild lowbush blueberry - Past and present. Small Fruits Rev. 3:229-255.

MacDermid Agricultural Solutions. 2014. Casoron G-4 granular herbicide. MacDermid Agric. Solutions Co., Guelph, ON, Canada.
McCully, K.V., M.G. Sampson, and A.K. Watson. 1991. Weed survey of Nova Scotia lowbush blueberry (Vaccinium angustifolium) fields. Weed Sci. 39:180185.

Miller, W.M., A. Schuman, J.D. Whitney, and S. Buchanon. 2005. Variable rate applications of granular fertilizer for citrus test plots. Appl. Eng. Agr. 21:795-801.

New Brunswick Department of Agriculture, Aquaculture, and Fisheries. 2017. Wild blueberry IPM weed management guide. Wild blueberry fact sheet C.4.2.0. New Brunswick Department of Agriculture, Aquaculture and Fisheries, Fredericton, NB, Canada.

Penney, B.G. and K.B. McRae. 2000. Herbicidal weed control and crop-year NPK fertilization improves lowbush blueberry (Vaccinium angustifolium Ait.) production. Can. J. Plant Sci. 80:351361.

Pritts, M.P. and J.F. Hancock. 1984. Independence of life history parameters in populations of Vaccinium angustifolium (Ericaceae). Bull. Torrey Bot. Club 111:451-461.

Sikoriya, S.K. 2014. Phenological study and management of red fescue (Festuca rubra) in wild blueberry. MSc Diss., Dalhousie Univ., Truro, NS, Canada.

White, S.N. and S.K. Kumar. 2017. Potential role of sequential glufosinate and foramsulfuron applications for management of fescue (Festuca spp.) in wild blueberry. Weed Technol. 31:100-110.

White, S.N. 2018. Determination of Festuca filiformis seedbank characteristics, seedling emergence and herbicide susceptibility to aid management in lowbush blueberry (Vaccinium angustifolium). Weed Res. 58:112-120.

White, S.N. 2019. Evaluation of herbicides for hair fescue (Festuca filiformis) management and potential seedbank reduction in lowbush blueberry. Weed Technol. 33:840-846.

Wood, G.W. 2004. The wild blueberry industry - Past. Small Fruits Rev. 3:1118.

Zhang, L. 2017. Management of perennial grasses in wild blueberry (Vaccinium angustifolium) fields. MSc Diss., Dalhousie Univ., Truro, NS, Canada.

Zhang, L., S.N. White, A.R. Olson, and K. Pruski. 2018. Evaluation of flazasulfuron for hair fescue (Festuca filiformis) suppression and wild blueberry (Vaccinium angustifolium Ait.) tolerance. Can. J. Plant Sci. 98:1293-1303. 